Elena Yu. Konstantinova

The Ilya Glazunov Russian Academy of Painting,

Sculpture and Architecture

Museum of Russian Icons

e-mail: ek.25@mail.ru

Moscow, Russia

ORCID 0000-0003-1042-5769

DOI: 10.36340/2071-6818-2020-16-4-19-32

\title{
PAVEL FLORENSKY'S CONCEPT OF THE ICON
}

Summary: This article is an analysis of the concept of the icon as seen by Pavel Florensky, a priest, philosopher of religion, and theologian. He expressed his views on the art of icon painting in the articles The Church Ritual as a Synthesis of the Arts, Devotional Icons of St. Sergius of Radonezh, and Reverse Perspective, as well as his work Iconostasis. Florensky's theory is of great interest for art history, contributing to it not only by highly evaluating Russian icons of the 14th and 15th centuries but also by offering a new approach to realism in art. Yet as his concept is complex, it is also controversial.

Viewing the icon as a work of art and following Plato's philosophy, Florensky believes the objective reality of the Realm of Ideas to be the basis of artistic creativity in general and icon painting in particular. According to him, the creation of art is not an artist's subjective search for the ways of self-expression but the result of the soul's ascent to the truth, the world of prototypes. The icon reflects divine reality and is thus realistic in nature. Highly evaluating the icon painting in the 14-15 century Russia, he believes Andrei Rublev's Holy Trinity to be an art masterpiece.

Between the end of the $19^{\text {th }}$ and the beginning of the $20^{\text {th }}$ century, European art was marked by events of immense importance. An active search for new forms in art was accompanied by a theoretical exploration of the ways to express new meanings. It was at the same time that the European art world saw some art forms previously unknown to it, such as medieval Russian icons. The icon stopped being exclusively a cult item and was evaluated as a piece of art.

A priest, theologian, and philosopher of religion, Pavel Florensky (1882-1937) tried to understand the Russian icon as a work of art that has an important place in the world art heritage and studied it from the interdisciplinary perspective, combining art his-
However, developing his concept, Florensky discards the term "image": for him, the icon is merely a symbol pointing to the prototype. The artistic image is born in the artist's soul and exists independently from the icon, and can then be born in the soul of the beholder, who is guided to the prototype by the symbol. This is how the icon, as a result of artistic creation, is reproduced in the person viewing it.

Florensky underlines the importance of aesthetics in assessing an icon, for a work's artistic perfection is inseparable from its ability to testify to the prototype, and beauty is measured with the truthfulness of this testimony. Yet by acknowledging the fact that all icons created according to the canon are of the same value, he renounces the artistic criterion and makes the masterpieces of icon painting equal to many other artworks of average quality.

For Florensky, the icon is an integral part of a synthetic work of art - the church ritual - and its existence as an art phenomenon is dependent on certain conditions: if these are not met, it "dies" as art.

Keywords: icon, Russian icon painting, visual object, artistic creation, imagery, art, image and symbol, realism.

tory, psychology, philosophy, and theology to create a complex image of the object at hand. His articles The Church Ritual as a Synthesis of the Arts (1918), Devotional Icons of St. Sergius of Radonezh (1919), and Reverse Perspective (1919), as well as his work Iconostasis (1922) are all devoted to this.

It is all the more important to analyze Florensky's concept in the sense of the classical Theory of Fine Arts $^{1}$ and evaluate his contribution to it since he uses its key concepts - image, symbol, allegory, and imagery - and reexamines the role of perspective as an element of art. Giving an elaborate analysis of the art process, creation and perception of

1. As defined by V. Arslanov in Zapadnoye iskusstvoznanie XX veka (Moscow, 2005). 


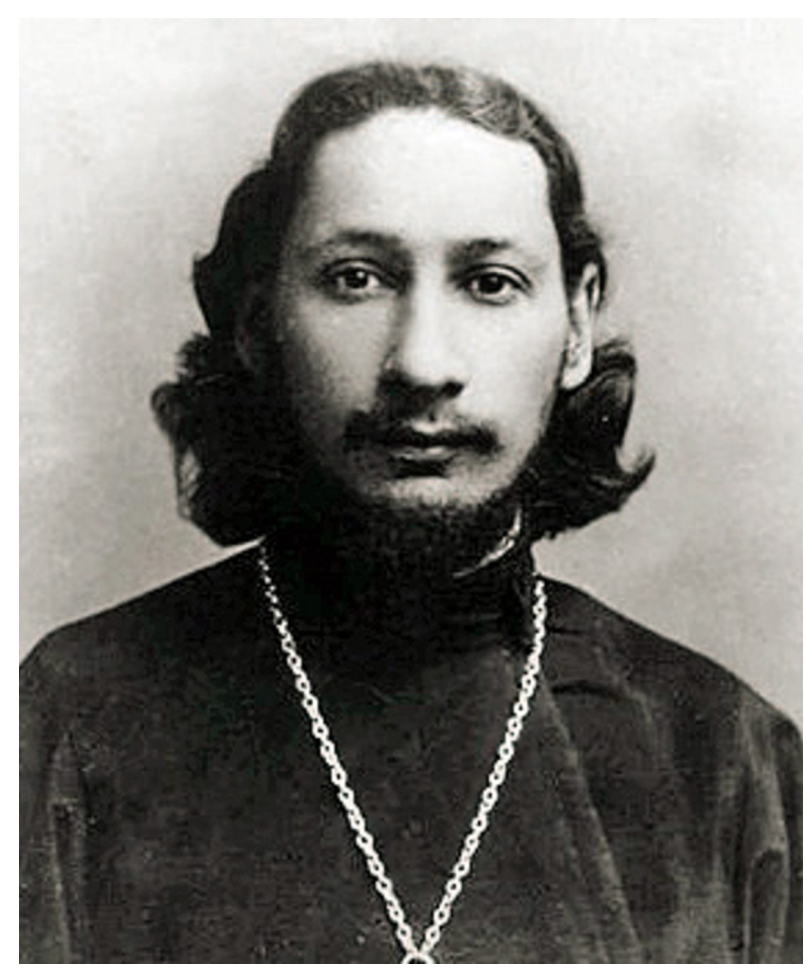

Pavel Florensky

a work of art, he raises the main question of what an icon is in its essence.

Florensky believes that artistic expression is crucial for humans and is of absolute value. The divine reality is reflected in art, and the true being is embodied in a sensory image. He notes that striking artistic evidence of revelation can be found in different periods of all cultures, but it is icon painting that Florensky says to be the highest form of art in the entire world heritage and the "historical origin" [7, p. 385]. The icon is built upon a system of principles and rules and relies on certain conditions in its creation, which makes it a work of art capable of reflecting the truth in the best possible way, and Florensky distinguishes the Russian icons of the $14^{\text {th }}$ and $15^{\text {th }}$ centuries as the "height of perfection without parallel in the whole history of world art" [9, p. 69].

A new approach to realism is one of the pillars of Florensky's theory of the icon. Relying on the medieval concept of philosophical realism, which opposes nominalism in the problem of universals (9-14 centuries), he says that this term should be applied not to the art that tries to reproduce the appearance of an object but the art that strives to perceive its ontological essence, i.e. turns to the divine reality. Florensky believes that naturalism is alien to true art, for it is nothing more than "an imitation of sensory reality, a duplicate of life that no one has a need for" [7, p. 384]. He argues that any art seeks to understand the divine reality, and it is especially true of icon painting, which is the pinnacle of art. Only those whose soul could see the "spiritual forms of things", their ideas, can be artists [9, p. 17]. He notes that the understanding of art in Christian theology rests on Ancient Greek idealism [7, p. 383] in the sense of Plato's philosophy, and thus he sees the process of art creation as a soul's ascent into the Realm of Ideas. The vision of the true forms, or "countenances", is "the fulcrum of all our earthy creativity" [9, p. 26], and reproducing the higher, true being, the "supreme heavenly beauty of a precise reality" $[9$, p. 28$]$ is, according to Florensky, the objective of art.

As a means of harnessing the freedom of an icon painter's creativity, the issue of the church canon is closely tied with realism. The "essential rationality of humankind" [9, p. 62], canon becomes aid to a painter's creative endeavors. By learning the canon, a painter obtains the true artistic freedom to depict the truth, for by harnessing his subjectivity, his "opinion" of the world, he opens himself to revelation. Yet this ascent to the highest prototype is not possible for all artists, though using prototypical icons as a source allows one to come in contact with divine reality that has already been depicted once, and see it, even if secondarily.

Florensky states that a true work of art is born from the source of all being, and the realism of the true artistic creation is in its essence "ontologism" [7, p. 384] and symbolism. Conceiving the concept of the icon, he uses three notions - image, symbol, and allegory - and his unique understanding of these notions is where lies the essence of his approach to the study of icon painting and art in general.

Florensky repeatedly uses the term "image"; he states that in the 14-15 centuries, the Russian icon painting had reached a height of perfection $[9, \mathrm{p}$. 69] and notes its high artistic value, but as he goes deeper into his analysis, he denies that an image has its own ontological reality. Saying that to represent something is "to establish a one-to-one correspondence between the points of the form and the points of representation" [8, p. 84], Florensky views an image as a representation of the physical form of a 3D object, its structure, on a plane, which is impossible without disrupting the form of the said object. Using a map as an example, he states that an image only represents an object when it makes us turn in spirit to the actual thing depicted, and does not represent if it detains us in itself as in some 


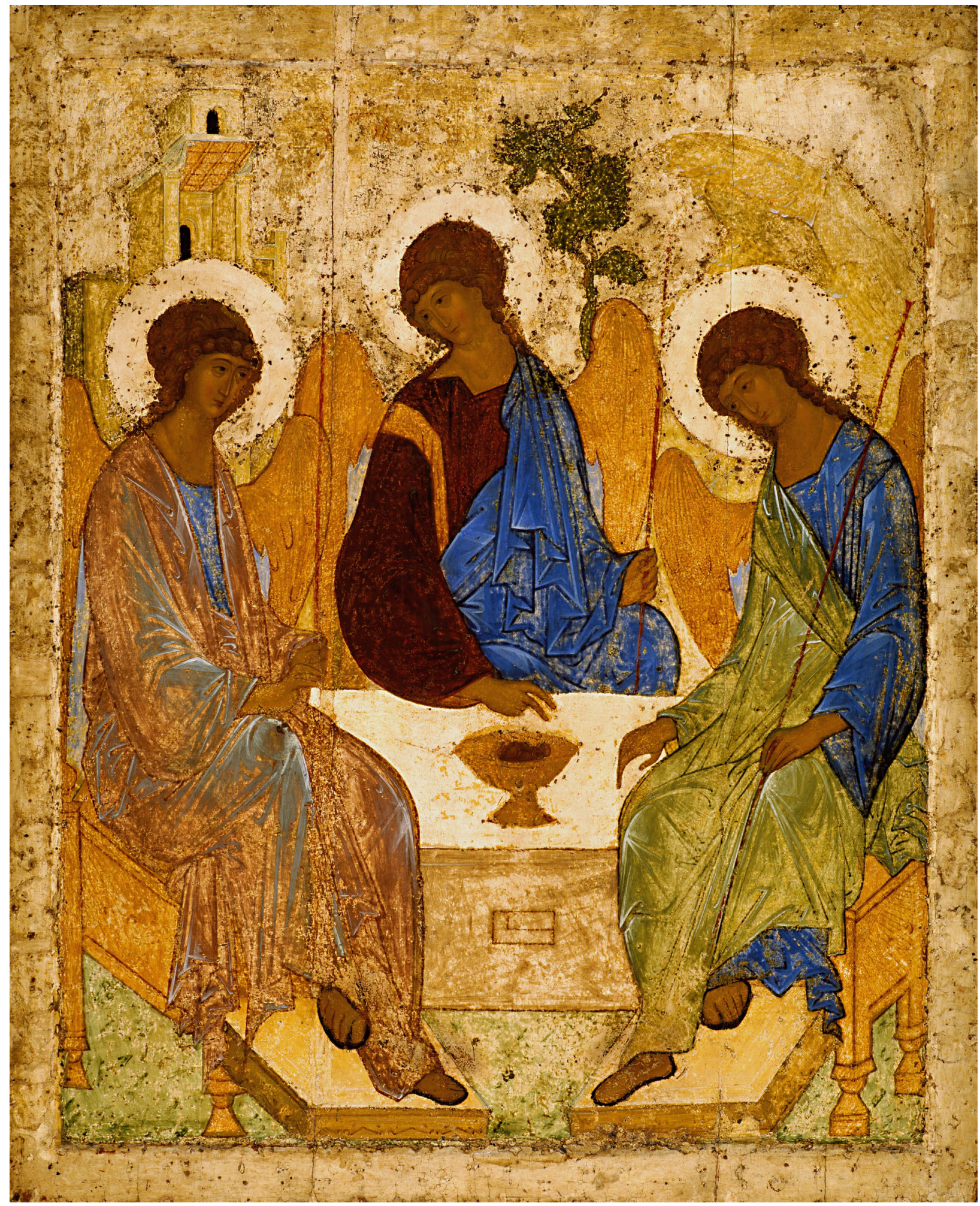

Andrey Rublev. The Holy Trinity. 1422-1427.

pseudoreality, a likeness of reality that lays claim to its own significance.

For Florensky, an image of an object is not an object, or a copy of an object, either, but is a symbol of it, i.e. an image does not exist by itself, has no being of its own, and its essence comes down to a symbol or allegory. The advantage of a symbol is that it does not call for an explanation but turns us directly to the prototype, as does, for example, an icon by Andrei Rublev. The antithesis of a symbol is an allegory, which does not directly and visually testify to the truth but tries to tell a story about it. Florensky points out that at the close of the $16^{\text {th }}$ century, the spirit of allegory shows itself in increasingly complex theological compositions, mysterious and abstract puzzles of the spiritual world, the 
act of solving which replaces the act of direct visual perception [9, pp. 68-69].

The icon cannot exist by itself as a work of art or an image. Florensky compares it to a window: just as a window is always either more or less than it is, either what you can see beyond it or simply glass, wood and metal, the icon is also a kind of a window that shows one an image but is not this image by itself. If the icon has no connection to the divine reality, it is merely a board with some paint on it, a sensory material $[9$, p. 43] devoid of any spiritual meaning, i.e. pseudoreality [8, p. 85]. Thus, the icon is not an image but a symbol that only "signifies, points to, implies, guides to the representation of the original" [8, p. 86]. Florensky notes that it may be spiritual only to the extent to which it is connected to the spiritual reality it refers to. The icon painter sees an image that came to their soul as a vision as it traveled and crossed the border between worlds, and depicts only its outline, its symbol, so the person praying before the icon can follow this symbol and acquire it in their own soul as well.

Turning to the history of the theological concept of the icon, Florensky points to the immense importance of the triumph of iconodulism over iconoclasm ( $9^{\text {th }}$ century) and notes that as a result of the controversy over icons, the "universal rationalism of humankind" $[7$, p. 383] proclaimed the absolute value of art. In his opinion, the existence of the aesthetic phenomenon testifies to the "personifiable and personified Absolute Value" and the "Absolute Meaning of being" [7, p. 384], i.e. confirms the truth of the Christian faith.

He believes that the best proof, or rather, testimony to the existence of the spiritual world is the fact that there are icon masterpieces such as the Holy Trinity by Andrei Rublev and the Virgin of Vladimir. The striking beauty of these icons, he thinks, leaves no doubt as to the existence of divine reality. These works cannot be a reflection of subjective vision but only a result of a revelation of truth, for according to the concept of realism, art is based on objective reality. He notes that this beauty opens equally to the spiritual and physical perception alike: it is not only intelligible but also visible, namely to the human eye. The high artistic quality of the best icons can be seen, and even though they are connected to the spiritual essence of the image, they are not overshadowed by it and have their own value. For Florensky, the beauty of the image is bound to the icon's ability to testify to the prototype, and beauty is measured with the truthfulness of this testimony. Truth is transfixed in the image, and its essence is perceived directly by the eye. Florensky states that the true artist strives for the beautiful or even "objectively beautiful" [9, p. 61]. The manifestation of beauty in the material world and the ability of the human soul to see, perceive, and strive for it is evidence of the divine presence and the divine nature of man. The beauty of the numinous world should be reflected in the beauty of the empirical world, for true beauty is born at the will of the higher law of the spirit and is an expression of it. The true spiritual experience cannot be depicted in images that are not beautiful, for beauty is inseparable from truth. According to Florensky, the object of icon painting is the "world created by God in its unearthly beauty" [9, p. 105], and the image of the icon in all its details is the image or reflection of the heavenly world, so it is impossible to discard the criterion of artistic perfection when evaluating the spiritual value of icons, for their aesthetic value is bound to their theological truth. The beauty of an icon, i.e. its artistic qualities, confirms that it corresponds to its purpose: to testify to the divine reality and guide people to it. Florensky proposes an idea that he believes is the most persuasive proof of the existence of God, "There exists the icon of the Holy Trinity by St. Andrei Rublev; therefore, God exists" [9, p. 47].

And here lies the first controversy of Florensky's theory. He notes that the Russian icon painting of the 14-15 centuries is a pinnacle of world culture and that it can only be compared to classical Greek sculpture in how perfectly it incarnates spiritual vision, thus acknowledging that these works of art are outstanding. Marveling at the beauty of Rublev's Holy Trinity and the Virgin of Vladimir, he says that such masterpieces should not be studied separately from all other icons. For him, icons of average artistic quality have the same value as the witnesses of truth since they follow the canon and are part of the icon painting tradition. Their ability to testify to the divine reality can be more or less concealed, and it depends on the viewer's spiritual state if they can or cannot penetrate this veil and feel the spiritual power of the image. The basis of every icon, be the artist highly skilled or not, is genuine spiritual experience, and thus any icon is a great masterpiece if it has devotional value.

With this statement, Florensky contradicts himself. First of all, he downplays the aesthetic evaluation of an icon and discards the value of beauty. 
He states that the icon is visual evidence of the true being that can be comprehended due to the perfection of its image, but then concludes that the "dimness" of artistic qualities can be overcome with the subject's spiritual effort. Thus, the artistic testimony to truth is not perceived directly with the eye, and truth itself does not clearly appear before the viewer but remains something to be comprehended with the mind, which means that the importance of artistic depiction of truth is rendered irrelevant, as is the value of aesthetics.

Florensky believes that the main meaning of an icon is inherent in it irrespective of its artistic qualities. Such a rejection of artistic evaluation means that the spiritual content of Andrei Rublev's icons, which Florensky refers to numerous times, and more primitive ones is the same and equal, so there are no grounds to separate true icon masterpieces from average works when comparing them.

Following Florensky's logic, one may conclude that the artistic perfection of the best Russian icons and Greek sculpture has no absolute value for art, and such masterpieces, like all other works, turn into a visual object that simply gives birth to some "vibrations" [8, p. 97] in the soul of the viewer. The highest spiritual content of these works is not comprehended through their artistic perfection: it can facilitate the process but is not crucial. The viewer's spiritual effort overcomes artistic imperfections, and the process of artistic creation and its perception becomes subjective rather than objective.

Thus, Florensky's theory rejects the notion of artistic perfection of a work of art, which inevitably means a loss of the grounds for artistic analysis. There is no longer any way to evaluate the aesthetic qualities of a work of art as the criteria of beauty and artistry are no longer needed. Art loses its unique features as a means of understanding the world, its borders become blurred, and classical art criticism loses the object of its study.

Another important aspect of Florensky's theory is that he does not see the icon as a physical object that has spiritual value in its entirety. According to him, the icon's main purpose is to testify to the heavenly world and thus it is unacceptable to view it in the artistic sense: the icon should only be studied from the religious, devotional perspective. Moreover, when an icon is removed from the church, it loses its "aesthetic reality" [6, p. 375] and ceases to exist as a work of art.
Florensky believes that artwork can only live in the space for which it was created and dies when not in the conditions familiar to it. True art is the unity of content and the means of its expression, but these means can be understood simplistically when a facet is taken away from the content-laden function of embodiment. The artistic meaning of the icon can only be brought to light by the entirety of acts performed in the church, acts that "become a constitutive part of the actual organism of the work of art and, having been foreseen by its creator, they form its continuation, although that too lies beyond the bounds of what we call, for the sake of brevity and simplicity, the work of art proper" [6, p. 375]. Without certain conditions, the aesthetic phenomenon of the icon is destroyed, so for Florensky, the interior of the church, the dancing candlelight, the fine veil of incense, and the singing are integral parts of the icon as art. The icon becomes a part of a complete, synthetic work of art, and loses its self-contained value.

Of course, internal conditions do affect how the viewer perceives artwork. But their importance lies in helping the viewer to find the artistic meaning objectively inherent in a work of art, not to bring it in from the Christian worship. A work of art is valuable by itself, and its artistic image does not depend on any conditions but is sealed once and objectively inherent in it. Florensky removes artistic meaning from the icon and thus robs it from objectiveness.

A painting has, first and foremost, a materialistic and idealistic component, which is its objective artistic image. This image is lost when the material basis of the painting (paint, canvas, board, etc.) is no more, for they are inseparable. A work of art that has two equal natures, material and spiritual, is aimed at depicting or reflecting the objective reality. For the Christian world view, the purpose of the icon is to depict the highest objective reality, which is God, and thus depict beauty, truth, and ethics. The artistic merit of a work of art depends on how accurately the artist managed to reflect the divine reality, so the artistic criterion is essential in its evaluation: this follows from the fact that a work of art carries in itself an image as a reflection of the prototype, which cannot be not beautiful or not truthful, etc. The artistic perfection of an icon determines how well it corresponds to its task, i.e. giving direct testimony to the heavenly world, the genuine reality. The beauty and harmony of an image are, in this case, a reflection of the absolute beauty and harmony. 
Yet for Florensky, the icon is not an image of God but merely his symbol, something that turns the viewer to him. Thus, the icon loses the main quality of a work of art - pictorial value - while the art theory becomes unable to give an artistic evaluation of icons. And if this quality, i.e. the lack of image, applies to art as a whole, it also loses the ground to be called fine arts.

Pavel Florensky's concept of the icon greatly contributes to art history not only by highly evaluating the Russian icon painting in the $14^{\text {th }}$ and $15^{\text {th }}$ centuries but also by introducing a new understanding of realism in art, yet due to its complexity it is also controversial to an extent.

First of all, he believes objective reality to be the basis of artistic creativity in general and the work of an icon painter in particular. For him, objective reality means the world of spiritual prototypes, and thus the icon is realistic because it depicts evidence of the highest realm of being. He sees the creative process not as a subjective search for the ways of self-expression but the result of the soul's ascent to the truth, the world of divine ideas, or prototypes.

Florensky discards the term "image" and views the icon as merely a symbol pointing to the prototype. Since the icon is not a painting, it objectively does not contain an artistic image, which is out- side of it and to which the icon can only point. As he notes, the image is born in the soul of the artist, and then the viewer guided by the symbol to the prototype also gives birth to it in their soul. A work of art should cause "vibrations" in the subject's soul, so they are awakened by these vibrations and can co-create the image in themselves. This way, the absolute objectivity of the creative process becomes subjective perception that is largely independent of the artistic qualities of the work of art.

Highly evaluating the artistic qualities of the Russian icons of the 14-15 centuries and speaking of the icon masterpieces' "triumphant beauty overwhelming everything" [9, p. 52], Florensky underlines the importance of aesthetics in assessing an icon. For him, the beauty of the image is bound to the icon's ability to testify to the prototype, and beauty is measured with the truthfulness of this testimony. Yet on the other hand, he acknowledges that all icons created following the canon have equal value, thus rejecting the artistic criterion.

Moreover, he denies the icon the completeness of its existence as a self-sufficient work of art. He believes that the icon may only exist as a part of a synthetic work of art - the church ritual - and "dies" as art if certain conditions are not met, which renders its scientific study impossible.

\section{REFERENCES}

1. Arslanov,V. 2005. Zapadnoe iskusstvoznanie XX veka [Western art history of the XX century] Moscow, Russia: Traditsiya. Akademitjeskij projekt. (in Russian)

2. Arslanov, V. 2011. "Isikhazm i teoriya ikony" ["Hesychasm and the theory of icons"], Sobranie [Collection], vol.2, p. 38-47. (in Russian)

3. Bychkov, V. 1990. Esteticheskiy lik bitiya (Umozreniya P. Florenskogo) [The aesthetic face of being: (The speculations of P. Florensky)], Moscow, Russia: Znanie. (in Russian)

4. Davydenko, M.V. 2009. Khudozhestvennost kak mnogoaspektniy fenomen $v$ trudah otechestvennyh filosofov kontsa XIX - serediny XX veka $v$ kontekste sovremennoy khudozhestvennoy praktiki [Artistry as a multidimensional phenomenon in the works of Russian philosophers of the late $19^{\text {th }}$ - mid- $20^{\text {th }}$ centuries in the context of modern artistic practice]. Dissertation, Candidate of Philosophical Studies: 17.00.09. Barnaul, Russia. (in Russian)

5. Esaulov, I.A. 2001. "Ekphrasis v russkoi literature novogo vremeni: kartina i ikona" ["Ecphrasis in modern Russian literature: painting and icon"], Problemy istoricheskoy poetiki [The Problems of Historical Poetics], vol. 6, pp. 43-56 (in Russian)

6. Florensky, P.A. 1996. Khramovoye deistvo kak sintez iskusstv [Temple action as a synthesis of arts]. Collected works, vol. 2. Compiled and edited by Hegumen Andronicus (Trubachev A.S.), Florensky P.V., Trubacheva M.S. Moscow, Russia: Mysl'. (in Russian)

7. Florensky, P.A. 1996. Molennye ikony Prepodobnogo Sergiya [Prayer icons of St. Sergius], Collected works, vol. 2. Compiled and edited by Hegumen Andronicus (Trubachev A.S.), Florensky P.V., Trubacheva M.S. Moscow, Russia: Mysl'. (in Russian)

8. Florensky, P.A. 2000. Obratnaya perspektiva [Reverse perspective]. Collected works, vol. 3. Compiled by Hegumen Andronicus (Trubachev A.S.), Florensky, P.V., Trubacheva M.S., edited by Hegumen Andronicus (Trubachev A.S.). Moscow, Russia: Mysl'. (in Russian)

9. Florensky, P.A. 2010. Iconostasis. Saint Petersburg, Russia: Azbuka-Klassika. (in Russian) 
10. Galinskaya, I.L. 2003. "P.A. Florensky o predmetah drevnego iskusstva" ["P.A. Florensky about objects of ancient art"], Vestnik kul'turologii [Bulletin of Kulturology], no. 3. (in Russian)

11. Kolesnikov, S.A. 2017. "The Theological Art History of Iconography in the Work of Priest Pavel Florensky: The Problem of the Face and Its Iconographic Representation" ["The Theological Art History of Iconography in the Work of Priest Pavel Florensky: The Problem of the Face and Its Iconographic Representation"], Khristianskoye Chteniye [Christian Reading], no. 2. (in Russian)

12. Osipova, N.O. 2017. "Florensky - Kandinsky - Kozhev: "mnimosty" ili "geometria"?" ["Florensky - Kandinsky Kozhev: "mnimosty" ili "geometria"?"], Sad raskhodyashchikhsya trop: Florenskiy, Rozanov, Durylin et cetera [The Garden of Forking Paths: Florensky, Rozanov, Durylin et cetera...] Materials of the All-Russian Conference, May 5-6, 2017, Moscow, Russia, pp. 29-31.(in Russian)

13. Samaryna, T.A. 2008. "Ontologicheskiye osnovy teorii iskusstva (P.A. Florensky and G.A. Gabrychevsky)" ["On- tological foundations of art theory (P.A. Florensky and G.A. Gabrichevsky)"], Izvestia: Herzen University Journal of Humanities \& Sciences, no. 60. (in Russian)

14. Zakharov, V.N. 2001. "Khristianskiy realism v russkoi literature (postanovka problemy)" ["Christian realism in Russian literature (problem statement)"], Problemy istoricheskoy poetiki [The Problems of Historical Poetics], no. 6. (in Russian)

15. Bakhurst, D. 2001. "Ilyenkov on Aesthetics: Realism, Imagination, and the End of Art", Mind, Culture, and Activity, vol. 8, no. 2, pp. 187-199. DOI:10.1207/ S15327884MCA0802_05

16. Koenderink, J., van Doorn, A. 2013. "Assemblage and Icon", Art \& Perception, vol.1, no.1-2, pp. 5-18. DOI: 10.1163/22134913-00002007

17. William A.P. Childs. 1988. "The Classic as Realism in Greek Art", Art Journal, no. 47, vol.1, pp.10-14. 


\section{КОНЦЕПЦИЯ ИКОНЫ П.А. ФЛОРЕНСКОГО}

\begin{abstract}
Аннотация: Данная статья посвящена анализу концепции иконы Павла Флоренского, священника, религиозного философа и богослова. Его мысли об искусстве иконописи изложены в статьях «Храмовое действо как синтез искусств», «Моленные иконы Преподобного Сергия», «Обратная перспектива» и труд «Иконостас». Теория Флоренского представляет большой интерес для искусствознания и вносит значительный вклад в него не только высокой оценкой произведений русской иконописи XIV-XV вв., но и введением новой трактовки понятия реализма в изобразительном искусстве. Однако являясь многосложной, его концепция имеет противоречия.

Рассматривая икону как произведение изобразительного искусства, Флоренский, следуя традиции платонизма, полагает основанием художественного творчества, и особенно работы иконописца, как его частного случая, объективную реальность мира духовных образов. Художественное творчество, по его мысли, является не субъективным поиском самовыражения художника, а результатом восхождения души к истине, к миру первообразов. Икона отражает высшую реальность и поэтому является искусством реализма. Высоко оценивая русскую иконопись XIV-XV вв., Флоренский считает икону Андрея Рублёва «Троица» шедевром изобразительно искусства.

Однако в своей концепции Флоренский отказывается от понятия изображения и икона для него представ-
\end{abstract}

Конец XIX - начало XX вв. в европейском изобразительном искусстве ознаменовалось событиями чрезвычайной художественной важности. Интенсивный поиск новых форм в художественной практике сопровождался теоретическими изысканиями возможности выражения новых смыслов. В это же время произошло открытие тех пластов художественной культуры, которые прежде были не известны европейскому худо- ляет собой лишь символ, указывающий на первообраз. Художественный образ рождается в душе художника и существует вне иконы, и затем может возникнуть в душе зрителя, который следует за изображенным символом к первообразу. Так икона, как созданное однажды художественное произведение, воспроизводится в сознании воспринимающего субъекта.

Флоренский подчеркивает важность эстетического критерия в оценке иконы, так как художественное совершенство произведения неразрывно связано с его способностью свидетельствовать о первообразе, и мера красоты является мерой достоверности этого свидетельства. Однако признавая одинаковую ценность всех произведений, созданных согласно иконописному канону, он отказывается тем самым от художественного критерия, и уравнивает шедевры иконописного искусства с множеством работ среднего художественного качества.

Для Флоренского икона является неотделимой частью синтетического произведения искусств - храмового действа и её существование как художественного феномена зависит от соблюдения ряда условий, без которых она «умирает» как художественное произведение.

Ключевые слова: икона, русская иконопись, визуальный объект, художественное творчество, художественный образ, изобразительное искусство, изображение и символ, реализм в искусстве.

жественному сообществу, в частности русской средневековой иконописи. Икона впервые перестала быть только культовым предметом и была оценена как произведение искусства.

Павел Александрович Флоренский (1882-1937) священник, богослов, религиозный философ, предпринял попытку осмыслить русскую икону как произведение искусства, занимающее важное место в мировом художественном наследии 
и обратился к её изучению на стыке различных дисциплин - искусствоведения, психологии, философии, а также богословия, создавая комплексный образ предмета исследования. Этому вопросу посвящены его статьи «Храмовое действо как синтез искусств» (1918 г.), «Моленные иконы Преподобного Сергия» (1919 г.) и «Обратная перспектива» (1919 г.), а также труд «Иконостас» (1922 г.).

Анализ концепции Флоренского в рамках классического искусствознания ${ }^{1}$ и оценка его вклада в науку об искусстве являются тем более важными, что при рассмотрении иконы он касается главных понятий данной научной дисциплины - изображения, символа, аллегории, художественного образа, а также пересматривает роль перспективы как художественного элемента произведения. Давая развёрнутый анализ процесса художественного творчества, создания и восприятия художественного произведения, он ставит главный вопрос чем по существу является икона.

Флоренский считает, что художественное творчество является чрезвычайно важной отраслью человеческой деятельности и имеет безусловную ценность. В произведении искусства находит отражение высшая действительность, и истинное бытие запечатлевается в чувственных образах. Он отмечает, что во всех культурах в разные периоды истории можно встретить поразительные художественные свидетельства явленного откровения. Однако среди всего мирового наследия иконопись выделяется Флоренским особо как высший род искусства и «исторический первоисток» $[12$, с. 385]. Икона строится на системе определённых принципов и правил и при создании требует соблюдения ряда условий, благодаря чему становится таким художественным произведением, в котором может быть наиболее адекватно запечатлена истина, и русскую иконопись XIV-XV вв. Флоренский выделяет как «единственную в мировой истории вершину» [11, с. 69] в изобразительном искусстве.

Одним из основных положений теории иконы Флоренского является новая трактовка понятия реализма. Опираясь на средневековую концепцию философского реализма, противопоставляемого номинализму в споре об универсалиях (X-XIV вв.), он указывает, что этим термином можно назвать не то искусство, которое ориентирует-

1. Понятие классического искусствознания сформулировано В.Г. Арслановым в труде «Западное искусствознание XX века». М., 2005. ся на воспроизведение внешнего облика объекта, а то, которое стремится постичь его онтологическое содержание, то есть обращается к истинной реальности. Подлинному искусству, по мнению Флоренского, не может быть свойственен натурализм, который является только «имитацией чувственной действительности, никому не нужным дублированием бытия» [12, с. 384]. Флоренский считает, что любое художественное творчество стремится к постижению высшей реальности, и в ещё большей степени это относится к иконописи как к его вершине. Художником может быть только тот, чья душа смогла увидеть «духовные зраки вещей» [11, с. 17], их идеи. Флоренский отмечает, что в христианском богословии понимание искусства опирается на традицию «древне-эллинского идеализма» [12, с. 383], то есть в духе философии Платона, и процесс художественного творчества воспринимается им как путь восхождения души в мир идей. Созерцание истинных сущностей, или «ликов», является «точкой опоры земному творчеству» [11, с. 26], а воспроизведение высшего, истинного бытия, «вечного смысла, пренебесной красоты» [11, с. 28] для Флоренского есть задача искусства.

С понятием реализма художественного творчества тесно связана проблема церковного канона как меры, которая регулирует свободу творчества иконописца. Канон становится помощью в творческих поисках живописца, являя собой «сгущенный разум человечества» [11, с. 62]. Постигнув его, художник обретает подлинную творческую свободу для запечатления истины, так как, сдерживая своё субъективное видение, «мнение» о мире, получает возможность открыть свой взор божественному откровению. Однако, по мнению Флоренского, такое восхождение до первообраза - удел не всех художников, но использование иконописных подлинников, как образцов, даёт возможность иконописцу прикоснуться к высшей реальности, уже запечатлённой однажды, и увидеть её, хотя и вторично.

Флоренский утверждает, что подлинное произведение искусства рождается от первоисточника бытия, а реализм истинного художественного творчества по своей сути является «онтологизмом» [12, с. 384] и символизмом. Выстраивая концепцию иконы, Флоренский оперирует тремя понятиями: изображение, символ и аллегория, и в особенности его понимания этих терминов заключается квинтэссенция подхода автора к из- 
учению искусства иконописи и изобразительного искусства в целом.

Флоренский неоднократно пользуется понятием «изобразить», например, он указывает, что русская иконопись XIV-XV вв. есть «достигнутое совершенство изобразительности» [11, с. 69] и отмечает высочайшую ценность её художественных качеств, но углубляясь в анализ этого термина, он отказывает изображению в его собственной онтологической реальности. Отталкиваясь от утверждения, что само понятие «изобразить» есть «установить взаимно однозначное соответствие между точками образа и точками изображения» [13, с. 84], он рассматривает изображение как перенесение физической формы объёмного предмета, его пространственной структуры, на плоскость, что оказывается невозможным без разрушения формы этого предмета. Приводя аналогию с географической картой, он утверждает, что изображение только тогда изображает предмет, когда отсылает духовный взор смотрящего к первообразу, и не изображает, если задерживает его на себе как на лже-реальности, подобии действительности, притязающем на собственную значимость.

Для Флоренского изображение предмета не является также предметом, копией вещи, но указывает на подлинник как его символ, то есть изображение само по себе существовать не может, своим собственным бытием не обладает, и суть его сводится или к символу, или к аллегории. Преимуществом символа является то, что он не нуждается в объяснении, а сам напрямую отсылает к первообразу, как, например, икона кисти Андрея Рублёва. Противоположностью символа является аллегория, которая, в отличие от него, не непосредственно, наглядно свидетельствует об истине, но как словесное повествование пытается рассказать о ней. Так, отмечает Флоренский, в русской иконописи с конца XVI в. дух аллегоризма проявляется в стремлении к сложным богословским построениям, к созданию загадочных, отвлечённых ребусов духовного мира, разгадывание которых заменяет собой непосредственное зрительное восприятие [11, с. 68-69].

Икона как произведение изобразительного искусства, изображение не может существовать сама по себе. Флоренский приводит аналогию с окном, которое всегда или более того, что оно есть, или менее, или оно то, что за этим окном можно увидеть, или просто стекло, дерево и ме- талл. Так и икона является неким окном, через которое человеку даётся образ, но сама она этот образ в себе не несет. Если икона не имеет связи с иной реальностью, то является лишь доской с красками, чувственным материалом [11, с. 43], лишённым всякого духовного смысла, то есть становится лже-реальностью [13, с. 85]. Таким образом, икона не является изображением, она символ, который только «означает, указует, намекает, наводит на представление подлинника» [13, с. 86]. Она может обладать духовным содержанием настолько, насколько имеет связь с той духовной реальностью, к которой отсылает, отмечает Флоренский. Иконописец видит образ, явившийся его душе при её путешествии и прохождении через границу миров, и запечатлевает только его очертания, его символ, следуя за которым, человек, молящийся перед созданной иконой, также в своей душе обретает этот образ.

Обращаясь к истории богословского осмысления иконы, Флоренский указывает на чрезвычайную важность победы иконопочитания над иконоборчеством (IX в.) и отмечает, что в результате полемики вокруг иконных изображений «вселенский смысл человечества» [12, с. 383] провозгласил безусловную значимость изобразительного искусства. Эстетический феномен, по его мнению, своим существованием свидетельствует «о воплощаемости и воплощённости Безусловной Ценности» и «Абсолютного Смысла бытия» [12, с. 384], то есть подтверждает истинность христианской веры.

Лучшим доказательством, а точнее свидетельством реальности духовного мира, Флоренский считает шедевры иконописного искусства, такие как икона Троицы кисти Андрея Рублёва и Владимирская икона Богоматери. Поразительная красота этих образов, по его мнению, не оставляет сомнений в объективном существовании высшей реальности. Появление подобных произведений не может быть отражением субъективного видения, а только свидетельством откровения истины, так как, согласно концепции реализма, в основании художественного творчества лежит объективная реальность. Флоренский отмечает, что в равной степени эта красота открывается духовному и телесному зрению, то есть она является не только умопостигаемой, но и воочию воспринимаемой, конкретно, человеческим глазом. Высокие художественные качества, присущие лучшим иконам, зримо воспринимаются и, хоть имеют связь с ду- 
ховным содержанием изображения, не затмеваются им и имеют собственную ценность. Для Флоренского красота изображения неразрывно связана со способностью иконы свидетельствовать о первообразе, и мера этой красоты является мерой достоверности этого свидетельства. В зрительном образе закрепляется удостоверение истины, и содержание его воспринимается непосредственно глазом. Флоренский утверждает, что стремление настоящего художника-иконописца направлено к прекрасному и даже «объективно-прекрасному» [11, с. 61]. Проявление красоты в материальном мире и способность человеческой души различать, воспринимать её и стремиться к ней является свидетельством божественного присутствия и богозданной природы человека. Это прекрасное сверхчувственного мира должно выражаться в прекрасном мира чувственного, так как истинная красота рождается по велению высшего закона духа, является проявлением его. Подлинный духовный опыт не может быть дан в образах не прекрасных, так как красота неотделима от истины. По мысли Флоренского, предметом иконописи является «Богозданный мир в его надмирной красоте» [11, с. 105], и изображение на иконе во всех своих подробностях есть образ или отобраз мира горнего, поэтому в оценке духовного значения произведений иконописи невозможно отказаться от критерия художественного совершенства, так как эстетическая ценность иконы непосредственным образом связана с её богословской достоверностью. Красота иконы, то есть её художественные достоинства, удостоверяют её соответствие своему назначению - свидетельствовать о высшей реальности и быть проводником к ней. Флоренский выдвигает тезис, который, по его мнению, является самым убедительным доказательством бытия Бога: «Есть Троица Рублева, следовательно, есть Бог» [11, с. 47].

Однако здесь проявляется первое противоречие концепции Флоренского. Он отмечает, что русская иконопись XIV-XV вв. является высшим достижением культуры и может быть сравнима по совершенству воплощения духовных образов лишь с греческой скульптурой, тем самым он признаёт художественные качества этих произведений выдающимися. Поражаясь красоте рублёвской Троицы и Владимирской иконы Богоматери, Флоренский указывает, что подобные шедевры не должны рассматриваться обособленно от всех иных произведений иконописи. Иконы среднего художественного уровня, по его мнению, имеют такую же ценность в качестве свидетелей истины, в силу соответствия канону и своей причастности к иконописной традиции. Их способность свидетельствовать о высшей реальности может быть под более или менее проницаемым покровом, и от духовного состояния созерцающего зависит возможность проникнуть сквозь него, почувствовать духовную силу изображения. В основе любой иконы высокого или невысокого мастерства лежит подлинный духовный опыт, и любая икона является высочайшим произведением искусства, если она обладает молитвенной ценностью.

Подобным утверждением Флоренский вступает в противоречие с самим собою. Прежде всего, он нивелирует эстетическую оценку художественных качеств иконы и отказывается от значимости категории красоты. Первоначально утверждая, что икона зрительно являет свидетельство истинного бытия, которое воспринимается благодаря совершенству изображения, далее приходит к мысли о том, что «замутнённость» художественных качеств того или иного произведения может быть успешно преодолена духовной работой субъекта. Таким образом, художественное свидетельство истины не воспринимается непосредственно, физическим зрением, а сама истина не предстаёт перед зрителем воочию, а остаётся только умопостигаемой, то есть важность художественного удостоверения истины нивелируется, как и ценность эстетического феномена.

Флоренский считает, что независимо от художественных качеств иконы, как произведения изобразительного искусства, в ней присутствует её главный смысл. Такой отказ от художественной оценки приводит к тому, что духовное содержание произведений Андрея Рублёва, на которые неоднократно ссылается Флоренский, и икон низкого художественного уровня одинаково и равнозначно, и при сопоставлении подобных произведений исчезает какое-либо основание для разграничения истинных шедевров иконописи и посредственных работ.

Следуя логике рассуждений Флоренского можно прийти к заключению, что художественное совершенство лучших образцов русской иконописи и греческой пластики не имеет абсолютной ценности для искусства, а подобные шедевры, как и все остальные произведения, превращаются в некий визуальный объект, рождающий в 
сознании зрителя лишь определённые «вибрации» [13, с. 97]. Высочайшее духовное содержание этих произведении постигается не благодаря их художественному совершенству, оно может лишь облегчить этот процесс, но не имеет принципиального значения. Личная духовная работа зрителя успешно преодолевает недостатки художественности, и процесс художественного творчества и его восприятия из объективной сферы перемещается в субъективную.

Таким образом, в теории Флоренского происходит отказ от понятия художественного совершенства произведения искусства, что неминуемо приводит к потере основания для художественного анализа. Всяческая возможность суждения об эстетических достоинствах того или иного произведения исчезает, так как утрачивается необходимость критериев красоты и художественности. Искусство, как один из способов познания бытия, теряет свою специфику, границы его размываются, и классическое искусствознание теряет объект изучения.

Еще одной важной особенностью теории иконы Флоренского является то, что он воспринимает иконописный образ не во всей полноте его существования как материального объекта, обладающего духовной ценностью. По его мнению, главным назначением иконы является свидетельство о горнем мире и потому неприемлемо рассмотрение её в художественном, изобразительном ключе, а только в одном, чисто религиозном, молитвенном. Более того, когда икона изымается из храма, теряется её «эстетическая реальность» [14, с. 375] и она перестает быть произведением искусства.

Флоренский считает, что художественное произведение живёт только в той среде, для которой оно было создано и при отрыве его от привычных условий - умирает. Истинное искусство, по его мнению, является единством содержания и способов выражения этого содержания, однако эти способы выражения могут пониматься упрощённо, когда из полносодержательной функции воплощения вырезается какая-нибудь одна грань. Полностью раскрывает художественный смысл иконы лишь совокупность происходящих в храме действий, которые «входят в самый организм художественного произведения и, предусмотренные творцом его, образуют его продолжение, хотя лежащее и за пределами того, что, ради краткости и упрощая дело, мы называем собственно ху- дожественным произведением» [14, с. 375]. Без определенных условий существования эстетический феномен иконы разрушается, поэтому для Флоренского интерьер храма, мерцающий свет свечей, тонкая завеса фимиама, звучание песнопений есть неотъемлемая часть иконы как художественного произведения. Икона становится лишь частью целого, некоего синтетического произведения искусства и теряет собственную ценность.

Следует отметить, что внешние условия, несомненно, имеют значение для восприятия зрителем того или иного произведения. Однако важность их заключается в том, чтобы помочь смотрящему выявить художественный смысл, объективно присущий произведению искусства, а не привнести его из вне - из христианского богослужения. Произведение искусства самоценно, художественный образ, содержащийся в нём, не зависит от каких-либо условий, он закреплён уже однажды в произведении и присущ ему объективно. Флоренский выносит художественный смысл за пределы иконы и тем самым лишает его объективности.

Живописное изображение имеет, прежде всего, материально-идеальную составляющую: объективный художественный образ. Этот образ теряется при утрате материальной основы изображения (красок, холста, доски и т. д.), так как составляет с ней единое и неразделимое целое. Художественное произведение, которое является целостностью и тождеством двух природ, материальной и духовной, имеет целью изображение или отображение объективного мира. Для христианского мировоззрения задачей иконы, прежде всего, является изображение высшей объективной реальности - Бога, а следовательно - красоты, истины, морали. Мера художественности произведения зависит от того, насколько точно автор отразил в нём высшую реальность, поэтому художественный критерий при оценке произведения необходим, это следует из понятия о том, что произведение несёт в себе образ как отражение первообраза, который не может быть не прекрасен, не истинен и т.д. Мера художественного совершенства произведения иконописи определяет то, настолько оно отвечает своей задаче - прямому свидетельству образов горнего мира - истинной реальности. Сама красота и гармония образа является в данном случае отражением абсолютной красоты и гармонии. 
Однако для Флоренского икона не есть изображение Бога, а лишь его символ, то, что к нему отсылает. Икона, таким образом, лишается главного свойства, присущего произведению изобразительного искусства - изобразительности, а теория искусства утрачивает возможность художественной оценки произведений иконописи. Если же подобное свойство - отсутствие изображения - распространяется на всё художественное творчество, то само искусство теряет основание называться изобразительным.

Концепция иконы Павла Александровича Флоренского вносит значительный вклад в искусствознание не только высокой оценкой произведений русской иконописи XIV-XV вв., но и введением новой трактовки понятия реализма в искусстве, однако, являясь многосложной, несёт в себе определённые противоречия.

Прежде всего, основанием художественного творчества в целом и работы иконописца как его частного случая Флоренский полагает объективную реальность. Для него такой реальностью является мир духовных образов, и потому икона, на которой запечатлевается свидетельство о высшей сфере бытия, является искусством реализма. Процесс художественного творчества мыслится Флоренским не как субъективные поиски выражения художника, а как восхождение его души к истине - миру божественных идей, первообразов.

Флоренский отказывается от понятия изображения и рассматривает икону как символ, указующий на первообраз. Он считает, что, не являясь изображением, икона объективно не содержит в себе художественный образ, который находится вне произведения, и к которому икона как символ только отсылает. Как отмечает автор, образ рождается в душе художника, а затем зритель, следуя за изображенным символом к первообразу, также рождает его в своей душе. Задачей произведения искусства является пробуждение в сознании субъекта «вибраций», и он, разбуженный этими вибрациями, уже имеет возможность сотворчески воспроизвести в себе картину. Таким образом, в теории Флоренского абсолютная объективность творческого процесса переходит в субъективность восприятия, мало зависящую от художественных качеств произведения.

Давая высочайшую оценку художественным качествам русской иконописи XIV-XV вв. и говоря о «всепреодолевающей победной красоте» [11, с. 52] шедевров иконописного искусства, Флоренский подчёркивает важность эстетического критерия в оценке иконы. Для него художественное совершенство произведения неразрывно связано с его способностью свидетельствовать о первообразе, и мера красоты является мерой достоверности этого свидетельства. Однако, с другой стороны, он признаёт одинаковую ценность всех произведений, созданных согласно иконописному канону, отказываясь тем самым от художественного критерия.

Кроме того, Флоренский отказывает иконе в полноте её бытия как самостоятельного произведения искусства. По его мнению, икона может существовать лишь как часть синтетического произведения искусств - храмового действа и при отсутствии соответствующих условий «умирает» как художественное произведение, что делает невозможным её научное изучение.

\section{БИБЛИОГРАФИЯ}

1. Арсланов В.Г. Западное искусствознание $X X$ века. - М.: Традиция, 2005; Академический проект, 2005. -862 с.

2. Арсланов В.Г. Исихазм и теория иконы. - Собраніе, 2011, № 2. - 38-47 с.

3. Бычков В.В.Эстетический лик бытия: (Умозрения П. Флоренского) / В. В. Бычков. - М.: Знание, 1990. -63 c.

4. Галинская И. Л. П. А. Флоренский о предметах древнего искусства // Вестник культурологии. 2003. № 3.
5. Давыденко М.В. Художественность как многоаспектный феномен в трудах отечественных философов конца XIX - середины XX века в контексте современной художественной практики: диссертация... кандидата философских наук: 17.00.09. - Барнаул, 2006. - 206 c.

6. Есаулов И.А. Экфрасис в русской литературе нового времени: картина и икона // Проблемы исторической поэтики. -2001. -Т. 6, С.43-56 
7. Захаров В.Н. Христианский реализм в русской литературе (постановка проблемы) // Проблемы исторической поэтики. - 2001. -Т. 6.

8. Колесников С.А. Богословское искусствоведение иконы священника Павла Флоренского: проблема лица и лика // Христианское чтение. - 2017. - № 2.

9. Осипова Н.О. Флоренский - Кандинский - Кожев: «мнимости» или «геометрия»? // Сад расходящихся троп: Флоренский, Розанов, Дурылин et cetera... М.: РГГУ, 2017. [Материалы Всероссийской научной конференции с международным участием 5-6 мая 2017 г.]. - С. 29-31.

10. Самарина Т.А. Онтологические основы теории искусства (П.А. Флоренский и Г.А. Габричевский) // Известия РГПУ им. А.И. Герцена. - 2008. - № 60.

11. Флоренский П.А. Иконостас. - СПб.: Азбука-классика, 2010. - 224 с.

12. Флоренский П.А. Моленные иконы Преподобного Сергия // Соч. в 4 т. Т. 2 / Сост. и общ. ред. игумена Андроника (А.С. Трубачева), П.В. Флоренского, М.С. Трубачевой. - М.: Мысль, 1996. - 877 с.
13. Флоренский П.А. Обратная перспектива // Соч. в 4 т. Т. 3(1) / Сост. игумена Андроника (А.С. Трубачева), П.В. Флоренского, М.С. Трубачевой; ред. игумен Андроник (А.С. Трубачев). - М.: Мысль, 2000. - 621 с.

14. Флоренский П.А. Храмовое действо как синтез искусств // Соч. в 4 т. Т. 2 / Сост. и общ. ред. игумена Андроника (А.С. Трубачева), П.В. Флоренского, М.С. Трубачевой. - М.: Мысль, 1996. - 877 с.

15. David Bakhurst. 2001. Ilyenkov on Aesthetics: Realism, Imagination, and the End of Art, Mind, Culture, and Activity, 8: 2, 187-199, DOI:10.1207/ S15327884MCA0802_05

16. Koenderink J., van Doorn A. Assemblage and Icon in Perception and Art, University of Leuven (KU Leuven), Utrecht University, Utrecht, 2013, Page Count: 5-18, DOI: 10.1163/22134913-00002007

17. William A.P. Childs. 1988. The Classic as Realism in Greek Art, Art Journal, 47:1 